\title{
Studying the role of the $G \alpha$-protein subunit GPA-3 in amphid channel cilia of Caenorhabditis elegans
}

\author{
A van der Vaart ${ }^{*}$ S Rademakers, G Jansen \\ From First International Cilia in Development and Disease Scientific Conference (2012) \\ London, UK. 16-18 May 2012
}

Many environmental cues are detected by G-proteincoupled receptors and relayed by heterotrimeric Gproteins to produce a cellular response. We recently found that a dominant active mutation in the $\mathrm{G} \alpha$-subunit gpa-3 (gpa-3QL) affects cilia development and function. Intraflagellar transport (IFT) is required for protein transport in cilia. Two kinesin motor complexes mediate anterograde transport in cilia of C. elegans; kinesin-II and OSM-3 (mammalian KIF17). Together they transport particles in the middle segment of cilia, while only OSM-3 enters the distal segment where it moves at a higher speed. Several mutants have been identified, including gpa-3QL, in which the two motors move at different speeds, and thus seem uncoordinated. The IFT particle composition in the gpa$3 \mathrm{QL}$ mutant remains elusive and our objective is to determine this using dual-colour live imaging of fluorescentlytagged IFT proteins. Constructs have been generated to express fluorescently-tagged IFT proteins and speed measurements have shown that the dynamics of the IFT proteins are affected by their expression levels, indicating that the stoichiometry of the IFT proteins is important for their coordination. We are currently determining the optimal conditions for dual-colour live imaging in cilia of wild type animals. In addition, we have performed a suppressor screen to identify novel proteins that play a role in cilia function. We have identified the E2 ubiquitin-conjugating enzyme variant UEV-3 as a suppressor of gpa-3QL. Dye filling and cilia length are restored in the gpa-3QL uev-3 mutant. Future experiments are directed to determine the precise role of UEV-3 in cilia formation and IFT.

Published: 16 November 2012

* Correspondence: a.vandervaart@erasmusmc.nl

Department of Cell Biology, Erasmus Medical Center, the Netherlands
doi:10.1186/2046-2530-1-S1-P57

Cite this article as: van der Vaart et al: Studying the role of the G $\alpha$-protein subunit GPA-3 in amphid channel cilia of Caenorhabditis elegans. Cilia 2012 1(Suppl 1):P57.
Submit your next manuscript to BioMed Central and take full advantage of:

- Convenient online submission

- Thorough peer review

- No space constraints or color figure charges

- Immediate publication on acceptance

- Inclusion in PubMed, CAS, Scopus and Google Scholar

- Research which is freely available for redistribution
() Biomed Central

\section{Biomed Central}

